\title{
The food superstore revolution: changing times, changing research agendas in the UK
}

\author{
*Alan Hallsworth \\ University of Surrey, School of Management, \\ Guildford, UK \\ Ronan de Kervenoael \\ Sabanci University, Faculty of Management, Istanbul, Turkey \\ and Aston Business School, UK \\ Jonathan Elms \\ Institute for Retail Studies, Stirling Management School, \\ University of Stirling, UK \\ Catherine Canning \\ Glasgow Caledonian University, Caledonian Business School, \\ Division of Fashion, Marketing and Retailing, UK.
}

*Email: a.hallsworth@surrey.ac.uk 


\title{
The food superstore revolution: changing times, changing research agendas in the UK
}

\begin{abstract}
This paper considers the changing scope of research into UK food superstores over a 30-year period. Rather than catalogue changing market shares by format, we seek instead to show how change links to national policy agendas. Academic research has evolved to address the growing complexities of the social, technological, economic and political impacts of the superstore format. We exemplify this by tracing the progression of retail change in Portsmouth, Hampshire, over 30 years. We discover that academic research can conflict with the preconceptions of some public policymakers. The position is exacerbated by a progressive decline in public information - and a commensurate rise in factual data held by commercial data companies - that leaves policymakers with a choice of which data to believe. This casts a shadow over the objectivity of macro-policy as currently formulated. Concerns currently arise because the UK Competition Commission (2008 but ongoing) starts each inquiry afresh with a search for recent data. Furthermore, it has recently called for changes to retail planning - the very arena in which UK superstore research commenced.
\end{abstract}

Keywords: Superstores, long term change, choice, policy, methodology

\section{Introduction}

In the UK, the freestanding, car-based, food superstore is now the hegemonic retail format. This outcome also applies in the USA and Canada: in large part due to the success of a single corporation - Wal-Mart. Varying regulatory regimes in other countries (for example, Germany, Wortmann 2004) mean that superstore dominance 
is not universal. The topic also remains problematic due to definitional distinctions between superstores and hypermarkets (see Hallsworth 1986) and the proportion of sales floorspace offered to non-food items etc. Indeed, the Competition Commission (2009) did not even use the terms superstore or hypermarket. Equally, wider public policy concerns also vary - making it prudent for us to focus on one country. The importance of the UK food superstore was first evidenced in land-use planning research that sought to understand and explain the phenomenon (Dawson 1983a; 1983b). Early academic work assisted planners by quantifying the impact of new stores via the gathering of information on which rival stores had lost trade or closed (for example, Hallsworth 1981a, 26; 1981b, 28). Characterised as the Retail Impact Study Approach, this was often basic but essential work (see Department of the Environment 1976a; 1976b; Dawson 1980; Dawson and Kirby 1980; Burt and Dawson 1990). It is of interest that, though planning remains a core concern, issues of competition and choice have risen in importance over time. We focus on outcomes in the Portsmouth area for several reasons. Firstly, because we believe that outcomes are locally mediated; secondly because retail change has been studied here for over 30 years; thirdly because both planning and competition/choice issues are raised. Indeed, the earliest empirical research was encouraged and supported by policymakers. Through time the Portsmouth research diversified - reflecting the rise of a more nuanced, grounded, sociological and contextualised view of the activity of shopping (Miller 1995). Part of the rise in concern over competition and choice reflects the reality that power in the UK retail market (Burt and Sparks 2003) has become increasingly concentrated into the hands of a "Big Four". There has also been a marked growth in the scale and scope of commercial data sources available to public policymakers. 


\section{Portsmouth, Hampshire, UK: the background.}

As noted, the early Portsmouth studies were supported by local Planning officials. Hallsworth (1988) offered a summary of the concerns felt by local planners as the superstore wave approached. For example, the County Planning Officer for Hampshire, Gerald Smart, had visited US downtowns and was on record as stating that a move to out-of-town or car-based shopping would blight established centres and disadvantage those dependent on them. The early factual reports offered a snapshot of the contemporary retail scene but patronage, even of the same retail format, can change as consumers' lifestyles evolve. Such topics have now been covered from research perspectives that transcend academic disciplines. There are, however, practical issues in generating the empirical data that were used in the past to investigate emergent trends in UK food shopping. The ability to collect data, and the willingness of the dominant superstore retailers to allow store access, has changed through time. Stores remain under pressure to allow data-gathering but are increasingly sensitive to their public image. Conversely, the original Portsmouth studies on superstore growth and impact were undertaken at a time when at-store data collection was much simpler. More superstores were locally-owned or controlled or had managers with the power to authorise at-store survey work. In the 1980s, Portsmouth-area research at five major freestanding stores offered a factual account of the characteristics of superstore consumers. The results were also of practical relevance to the retailers themselves: another reason why access to stores was granted. In 2002 (with results published in 2006) the ESRC provided the resources necessary to replicate/ revisit these stores (and newer rivals). The purpose was to replicate the original work and to undertake additional in-depth household-level studies to identify policy implications of ongoing changes in food shopping habits. Without the 
legitimation offered by Government support, access to store-based data would have been difficult. That said, it was not the at-store work but the household-level interviews in Portsmouth, 2002, that confirmed shopping as deeply-contextualised and locally-constrained (Jackson et al. 2006). Subsequent e-shopping research in 2008 in the Portsmouth area brought forth yet more such dimensions.

\section{Broadening academic perspectives and the increasing privatisation of knowledge}

Impact studies - rooted in patterns of retail structures and hierarchies - meant that social welfare issues were prominent, with concerns expressed about disadvantaged shoppers (Bowlby 1979; Bromley and Thomas 1992; Piacentini, Hibbert, and Al-Dajani 2001). The late Ross Davies (1978, 133-135) only briefly alluded to competition/fair trading topics before quickly passing on to planning and asking whether planners were "justified in concentrating new retail investments into traditional city centres, if redevelopment had really achieved “revitalisation” and whether "the problems of small businesses...can be alleviated".

It is fair to say that all of Davies' concerns remain priorities 30 years later. However, his writings followed an intensive period of plan-making by County Council Authorities: an activity then largely uncontested. That said, Hillier Parker's Russell Schiller was a frequent critic of planners' concerns for an orderly retail hierarchy as he wrote of "three waves" of retail decentralisation. John Dawson (Dawson 2000) looked at policy controls on hypermarkets and mentioned 1972 and 1976 policy guidance produced in the UK and informed, in part, by Impact Studies

(e.g. Dawson, Findlay, and Sparks 1986, 2). Their 1986 study of a Fine Fare store in Elgin concerned a once common fascia; one of dozens to have disappeared from UK High Streets in the intervening years (see for example, Hallsworth 1992, 116). 
Just some of the topics that UK superstore researchers have since covered include logistics and supply chains (Fernie and Sparks 1998) as well as retail productivity (Hall, Knapp, and Winsten 1961; Reynolds, Howard, and Dragun 2004) - often because of Government concern over alleged poor levels of productivity in the UK economy. Studies have also been made of foreign retail rivals, for example the now-increasingly-successful "hard discount" firms such as Aldi, Netto, and Lidl (Burt and Sparks 1995). Note has been made of a return to many high streets (Langston, Clarke, and Clarke 1997; Hallsworth and Bell 2003) as a response to the perceived success of the Co-ops and other "new" convenience store formats. There are, too, rising sensitivities about negative publicity - with some superstores embroiled in debates over the sourcing of low-cost items from countries with extremely low wages. In the last few years the extent of power of the Big Four in the UK retail market has become, in itself, a contentious topic. Others have traced food deserts (Guy, Clarke, and Eyre 2004) and complaints have arisen regarding the sameness and dullness of the current UK retail scene. Lobby group perspectives (New Economics Foundation 2005; 2006; Simms 2007) also stress the homogenising nature of superstore dominance.

Meanwhile, commercial data sources have grown in importance and a turning point was the 1979 decision to cancel the 1981 Census of Distribution (Sparks 1996). Nationally-available census data was thereby lost. Arguably the voice of civil society, which might speak for weaker/excluded social groups, was muted by the loss of objective census data. One major data concern for policymakers, the contrasting evidence on the alleged decline of small shops, has recently been covered by Wrigley et al. (2009) to which reference should be made. Databases now go beyond the exercise of shop-counting and some have even argued that price-comparison 
databases could assist corporate price-collusion. Academics lacking access to storebased data may use Mintel files (e.g., Mintel 2007) that offer data on product sales trends by gender, age, socio-economic group, tenure, ACORN category, and education. ACORN, like its MOSAIC counterpart and others, offers privately-held knowledge that has grown exponentially since the 1980s. Other familiar providers include William Reed, Verdict, IGD, and Taylor Nelson Sofres. Accordingly, academics hold no monopoly on the means to analyse aspects of the development of superstores. However, aggregate data do not permit academics to analyse more nuanced outcomes in localities: including social welfare concerns.

\section{Shopping in local context and the 1980-2002 Portsmouth studies}

In line with that search for nuanced outcomes in localities, the ESRC-funded research (2002), stressed how different even adjacent localities can be. The studies were finally published in 2006 (as Clarke et al. 2006; Jackson et al. 2006 - see also Kirkup et al. 2004). It was found that consumers have variable information - they perceive and experience retail options differently - and that car-based retail outlets affect pre-existing retail provision. Simultaneously, UK grocery retailing has seen market concentration towards a few superstore chains - leading the Competition Authorities to assess competition in terms of their presence. A debate has raged since 1996 when attempts were made to redress the spatial balance back towards the more central locations in which substantial past public investment had taken place. With supply of lucrative out of town locations slowing post-1996, this caused consternation among those - notably Asda/Wal-Mart - who wanted more (see Sparks 2008).

Portsmouth, in terms of demographic and lifestyle characteristics, represents a cross-section of "Middle England". Contrasting the surveys of 1980 and 2002 we 
found a general decrease in journey times to stores and a marked increase in the proportion of shoppers using a store within ten minutes of where they lived or worked (up from $49.2 \%$ to $71.6 \%$ ). Given that levels of car ownership had increased, a far higher proportion of food shopping in 2002 was carried out somewhere close (in timedistance) to where people lived or worked. Commensurately, the frequency of food shopping had increased markedly (the number of customers shopping three times a week, for example, having increased from $9 \%$ in 1980 to $21 \%$ in 2002).

A combination of the following factors - and more (see de Kervenoael, Clarke, and Hallsworth 2006) - is likely to account for this:

- More hectic lifestyles (the UK works more hours and has fewer statutory holidays than much of mainland Europe).

- A greater proportion of food being sold that is "fresh" or chilled (with attendant sell-by dates) rather than dry packaged goods or basic foodstuffs.

- The rise in less formal mealtimes and the attendant rise (driven by the large multiples themselves) in the cook-chill ready-meal market (several of the sample stores also had "takeaway" sections for ready-cooked hot food).

- Increasingly complex working patterns and lifestyles with some households having several part-time/low-waged jobs.

- Irregular access to weekly finances (this was explored in more detail in Jackson et al. 2006).

- The rise of "new" convenience stores catering to single-person households such as students (a massively increased number over 1980) and others with low consumption patterns, poor cooking opportunities or restricted storage facilities. (shopping alone was up from 42.5\% in 1980 to $71.9 \%$ in 2002 whilst convenience and/or location was the most important driver for shopping at any given store.)

- Extension of sales floorspace of larger stores to include clothing, electrical goods, etc....boosted first by "grey" market sourcing and then by imports from post-WTO China.

- The reality that it remains difficult for elderly customers, or those without a car, to patronise the larger stores.

From 1980 onwards, Portsmouth shoppers migrated to the superstore format whether by active choice or because alternative outlets closed. The second Portsmouth paper (Jackson et al. 2006) stressed the importance of the structure of particular households and the constraints that household conditions imposed on the 
assumed free spatial switching that underpins so many economistic notions of freedom and choice.

Analysis of trends 1980-2002 suggest that most of the deeper factors determining store choice were broadly the same in 2002 as they had been over twenty years earlier. However, by 2002, all neighbourhoods were closer to such stores. Food shopping provision in the Portsmouth area therefore saw shoppers exhibiting behaviour driven by convenience and geographic proximity. Essentially, food shopping behaviour is fitted into complex lifestyles rather than being driven by pricefixated consumers exerting free choices, unhindered by local context. Such a view is sceptical of any vision of consumer choice that ignores lifestyles and the more polarised income backgrounds of 21st-century Britain.

Note, too, that research seems to be running ahead of policy: which still presumes that purchase decisions are based on price and proximity. Conversely, academics are even questioning if purchase decisions are indeed free choices and asking to what degree consumers experience genuine choice once they are inside a store. Captive shoppers may purchase a wider range of goods than they perhaps intended. Furthermore, is it past purchasing history that determines what goes on the shelves or a complex and largely secret power-play between retailers and their suppliers? (see the case study in The Grocer 2007). This challenges those policymakers who are merely interested in mechanistically optimising their particular vision of consumer welfare.

\section{The contested concept of choice}

That there is no typical UK consumer carries repercussions for the definition and framing of the difficult concept of food retail choice. Portsmouth research showed 
that, if unconstrained, the shopper may chose between store fascias, between particular store branches or from whatever items are then found on the shelves. From 2006, a particularly interesting finding was:

\footnotetext{
‘Retailers’ own product brands (including non food areas) have also become a powerful vehicle for them to exert their presence locally and, when retail fascias gain standing as 'brands' in their own right, consumers can effectively 'lock' themselves into a particular retail format, thereby potentially reducing their field of 'choice', or voluntarily abrogating choice.' (Clarke et al. 2006, 27)
}

The extreme scenario of abrogation of choice confirms that the public does not necessarily use the physically-nearest large store. This seriously undermines lesssocialised, more economistic-deterministic modelling approaches which make precisely that basic assumption about behaviour. The 2002 Portsmouth work also argued that how consumers used such stores was itself linked to retailers' supply strategies to reinforce their power over local markets (Cotterill 1986; Dobson and Waterson 1996; Marion et al. 1979). The rise in the power of large retailers may also be reinforced by their ability to draw trade over larger catchment areas as a result of pricing structures derived from operational economies of scale and buying power (Burt and Sparks 2003; Guy 1990). It was long ago noted that such price advantages might drive out other forms of local competition such as small independents (Dawson and Kirby 1980; Clarke 2000). For example, according to the Meat and Livestock Commission, independent butchers made up nearly half the market (volume of meat sales in the UK) in 1977, but by 2005 held only 13.8\% of a $£ 5.4$ bn retail market with supermarkets taking a 75\% share (Pimlott 2005).

The inherent advantages of freestanding car-based retail outlets have now created a competitive environment that reinforces their ongoing growth and means 
that, for many shoppers, the only real choice is which superstore to use. Superstores have supply price advantages, free parking, and pro-rata, lower taxes. Their dominance is usually just portrayed as being more efficient and giving the consumer better choice - yet they are simultaneously reducing choice by eradicating much of their competition. The notion of consumer "choice" has therefore become a politically-charged term. DuGay (1996) links enterprise culture itself to the view that consumers are autonomous, self-regulating individuals. For some, choice has become canonised as the most precious of all consumers' rights and a source of "real power" (Lawlor 1989, 11). The National Consumer Council (1999 - also Straughan 1992), for example, argues that the principle of free choice is justified economically in terms of market efficiency. However, the Portsmouth, 2002 work found that some shoppers by-passed one branch of their 'preferred' store chain to reach another much more distant one even though store prices were likely to be the same - an extreme exercise of choice. Note, too, that a recent edition of Journal of Business Research (e.g. Lee, Fernandez, and Hyman 2009) has been devoted to the rise of the concept of choice/ anti-choice and outlines so-called voluntary positive consumer resistance (Hogg 1998).

\section{Superstore avoidance: the example of non-store shopping.}

Arguably we could ignore non-store shopping as it diverts us away from our core subject: the superstore format. However, three factors suggest otherwise: one being that market-leader Tesco itself is the dominant grocery home-delivery player. Secondly, the Competition Authorities have broadly neglected this topic as a factor. Thirdly, additional Portsmouth-based e-shopping research was conducted in 2008 and it casts further doubt on the notion that the hegemonic superstore is universally loved. 
This 2008 - ethnographic - study aimed to generate empirical insights into the interrelationship between consumers' at-store and Internet-based choices at the local level. Critical comparisons were facilitated because most respondents in the eshopping study also shopped off-line. Their behaviour unravels the complex domestic situations that mediate the choice to shop at-store or to go online. Some research based on interview data has suggested that Internet-based grocery shopping adds little variety to consumers’ grocery choices (e.g. Clarke, Kirkup, and Oppewal 2007). Conversely, the new findings are drawn from multiple methods (interviews, kitchen visits, accompanied shopping trips etc) and demonstrate that Internet shopping is, for some households, the preferred method for purchasing the majority of everyday shopping. The data are too rich for us to cover here but they will be published in due course (further details from the authors on request). They already reveal that, as larger superstores exert monopoly control over specific local areas, some residents use eshopping to avoid an at-store experience that forces them into an environment where neither fellow shoppers nor the general ambience are appealing to them.

These 2008 findings emphasise that shoppers cannot entirely avoid superstores and so continue to use them (albeit not always happily or willingly). They use superstores frequently but spend less time and money than an average in-store visit. This undermines the distinctions that regulators make between "one-stop” and "topup” shopping: the former allegedly reserved for medium and larger sized stores.

\section{Choice and the growing influence of UK Competition policy}

A growing emphasis on choice arises because an increasingly concentrated UK market has caused the Competition Authorities to wield increasing power. Choice, alongside low price, is a prime concern of the UK's Competition 
Commission. Burt, Hallsworth, and Reynolds $(1997,2)$ found they had produced an “environment far less hostile to the growth of market dominance than is the case in the United States” and this has actually led to a loss of choice when measured by store fascias. An earlier Competition Commission study on Supermarkets (2000) claimed they had identified local markets with too few stores or too heavy a reliance on few retail brands, and recommended that consumer choice needed to be increased and fostered. [Perversely, it was the Competition Commission's own lax merger policies that created this concentrated market.] Their viewpoint has since been reinforced by the pronouncements of the 2006-8/9 Competition Commission Groceries Inquiry (2008). They demand more choice nationally: but only if this increased choice comes in the form of more outlets of the remaining food store developers. This raises many issues of which we can note just a few. At the widest level their now-proposed retail fascia test (see Hughes et al. 2009) affects local democracy because it provides topdown direction to localities from an outsourced, unelected, Agency of UK Central Government. In their Remittal Response to having been forced back to the drawing board by Tesco, the Competition Commission admitted that Tesco had "submitted that the Test would limit the power of elected councillors to authorize investment in their areas” (Competition Commission 2009, 23). Of note, too, is another point made by Tesco who claimed "that the most significant 'off-model' impact of the Test was in relation to non-food provision. It said that, since 60 per cent of the space added by extensions across the industry over 2000 to 2006 was to enhance non-food retailing” (2009, 23). This stresses again our earlier point about the fluctuating and often significant effects of the amount of floorspace devoted to non-food. Tesco thus illustrate the limitations imposed when the Groceries Inquiry chose to ignore this trend. That same remittal response carries insights on and in their revised approach, 
for example: "We have not conducted a detailed textual analysis of the report to identify precisely the elements that were quashed as a result of the Tribunal's decision, nor have we attempted to rewrite the report in the light of its judgment.” (2009, 4). This has not prevented the Competition Commission from inviting Planners to re-introduce the fascia diversity that was lost when the Competition Commission itself approved past mergers and takeovers. Nor have they been prepared to countenance reversing their past policies and activating store divestitures or corporate de-merger as a means to restore fascia choice. Their chosen approach merely invites existing chains to increase their coverage and so national policy may have been collapsed to cover just a few private sector firms. This imposed, national, vision sits uneasily with the fact that the Big Four have distinctly regional - not national origins. For example, Jones $(1981,199)$ wrote of ASDA’s “(only).....gradual extension of their market area away from the original base in West Yorkshire” that had not reached much beyond Lancashire. The exceptions were Wrexham, Wales, Scotland (in May 1976 they opened their $38^{\text {th }}$ store - in Aberdeen) and Nottingham. The latter, as Whysall (2005) recorded, was an existing store that ASDA had purchased from GEM.

The Competition Commission's call for more car-based stores also seems perverse at a time when environmental concerns are at all-time highs and is likely the result of two factors. First is the highly-limited vision of choice and/or competition held by the Commission's economists. Secondly, they chose the SSNIP - small but significant non-transitory increase in prices - test (Cotterill 1986) but lacked the means to model anything other than large stores. The SSNIP test makes assumptions about spatial switching by shoppers if a local store raises prices. Inevitably, a price-driven 
econometric vision cannot accommodate the 30-years of more insightful, grounded, nuanced research to which we have alluded. As they put it:

"Using data from the shopping behaviour of approximately 13,000 UK households, we constructed an econometric model to explain consumers' choice of grocery store. ...we use this model to predict the behaviour of households in response to a change in the non-price components of PQRS ...In predicting how households would react to a worsening of the offer at a store where they currently shop, we assume that those households facing a worse offer would change their choice of store in a way that was consistent with those households with similar characteristics that currently face a worsened offer.” (Inquiry final report 2008, 59 - emphasis added)

Left unquestioned is why, in the competitive market that Competition authorities have been seeking for decades, any store chain would risk worsening its offer. That chains such as Tesco responded to the current recession with the introduction of cheap discount lines is similarly disregarded. Even on their own terms, there are problems and they thus invited Professor Margaret Slade of Warwick University to give an expert opinion "on the validity of the econometric evidence". She wrote that "the Competition Commission regressions do not capture all of the motives for and effects of entry and some of the estimated effects may be biased” (Slade 2008 expert opinion, 1, 4). Peter Freeman (2008) the Chair of the Competition Commission, himself conceded that their approach (the SSNIP test) had been criticised in some quarters for having a "breathtaking naivety and narrowness of mind". This merely reinforces the perpetual need for academics to monitor what is seen by others as relevant information.

Their restricted, econometric, visions of choice also cannot encompass effects such as the resistance-to-switching effects proposed by Warde (2005) and others. They have, however, displaced the social welfare concerns of 30 years ago: which 
may, sadly, also reflect a decline in the status of Planning and in the numbers of retailcompetent planners (Baldock 2009). For example, the Government’s July 2008 consultation on Planning and Town Centres (DCLG 2008) presents as a fait accompli the abandonment of the influential Planning "need test" that had been introduced following PPG6 of 1996 (see Wood, Lowe, and Wrigley 2006).

In the formal/regulatory debate about what constitutes choice, little use has been made of findings such as those from Portsmouth. What may blandly be viewed as an expression of choice driven by free will is often subject to the fact that consumers are themselves constrained or routinised by everyday life. The sociallyembedded nature of people's actual shopping practices (Fine, Heasman, and Wright 1996; Miller 1995; Miller et al. 1998) means that they are often constrained within a particular geographical and social context. This challenges econometrics-driven policymakers to prove that they have the scope to judge whether retail developments really do lead to a net benefit or improvement in consumer choice.

\section{Summary and Conclusions}

We have noted the varietals of a body of research that documented routine food shopping in Portsmouth some 30 years ago. That research, like its later replication, was a product of changing times. We have identified the conditions under which data-gathering has changed and also seen that research has become more complex, contextualised and politicised. A good recent example of this is Sparks (2008) for we alluded earlier to store expansion plans. Planning has long been seen as a hindrance to this, so Sparks' revelations on political lobbying (see also Wrigley 1993; Pal et al. 2001) are extremely timely.

Overall, we have seen an explosion in the scope and nature of superstore 
research - driven by the fact that freestanding big-box stores are now hegemonic in the UK. This leads us to conclude that the earliest studies tapped into a rich and worthwhile vein of research. However, a parallel trend has been the loss of choice as measured by High Street store fascias such as Fine Fare (once part of the Canadian Weston empire) or Shoppers Paradise. This reflects the UK's lax policies on mergers and takeovers. The transformation of the UK food retail scene has lately continued with the acquisition of Safeway by Morrisons and Somerfield by the Co-operative Group. The same Competition Authorities that validated these mergers now assert that choice has been lost - and can only be restored by forcing planners to accept new stores from the major chains still left. The likely consequence of this is demonstrated by Hughes, Clarke, and Hallsworth (2009 forthcoming) who, using the Commission’s own metrics, found that a majority of hypothetical new stores would easily pass the “test”. It appears that retail policy has come full circle back to planning but is now driven not by planners themselves but by Competition econometricians who blithely disregard the three decades of academic retail research upon which we have reported. 


\section{Acknowledgements}

We are grateful to the editors and to anonymous referees for helpful comments on earlier versions of this paper.

\section{Notes on contributors}

Alan Hallsworth is Professor Emeritus, Staffordshire University. He was formerly a Professor in the Department of Retail Marketing at Manchester Metropolitan University and has held posts at the Universities of Surrey and Portsmouth and Manchester Business School. Alan's interests include researching the policy agendas underpinning the competitive effects of large superstores on small shop rivals - an interest that he also pursues in Canada. He is a member of the Board of the Foundation for Canadian Studies and has held a number of other Canada-related posts.

Ronan de Kervenoael is a lecturer in consumer behaviour and retailing at Sabanci University, Istanbul, Turkey and a network lecturer in Marketing at Aston Business School, UK. He previously held a lectureship at Lancaster University in the Marketing Department. Ronan has a particular interest in groceries and staples goods shopping investigating consumer behaviour, routine and shift in practices from a local perspective. He is also pursuing research on long term retail change and the e-retail channel governance both in Britain and Turkey.

Jonathan Elms is a lecturer in marketing and retail studies at the Stirling School of Management, University of Stirling, Scotland. He was previously a teaching fellow at Lancaster University Management School. Jonathan's research interests fall under the umbrella of the changing (virtual) geographies of retail provision, the socio-spatial contexts of consumption, and interpretive research methodologies.

Catherine Canning is a senior lecturer in consumer and organisational behaviour at Glasgow Caledonian University in the Division of Fashion, Marketing and Retailing within the Caledonian Business School. Catherine was awarded an MSc in Marketing from the University of Strathclyde, Glasgow, in 2002 and previously worked in a variety of management positions in the food industry for 10 years after completion of her undergraduate degree. Her research interests include consumer behaviour and fashion, ethical consumer behaviour and food and fashion retailing.

\section{References}

Baldock, J. 2009. Education for Retail Planning - An Initial Scoping Paper. http://www.nrpf.org.uk

Bowlby, S. 1979. Accessibility, mobility and shopping provision. In Resources and planning, eds. B. Goodall and A. Kirby, 293-323. Oxford: Oxford University Press.

Bromley, R. and C. Thomas. 1992. The retail revolution, the car-less shopper and disadvantage. Transactions Institute of British Geographers 18: 222-236.

Burt, S. and J. Dawson. 1990. From small shop to hypermarkets: The dynamics of retailing. In Western Europe: challenge and change, ed. D. A. Pinder, 141-161. London: Belhaven Press.

Burt, S. and L. Sparks. 1995. Understanding the arrival of limited line discount stores in Britain. European Management Journal 13(1): 110-119.

Burt, S. and L. Sparks. 2003. Power and competition in the UK retail grocery market. British Journal of Management 14: 237-254.

Burt, S., A. G. Hallsworth, and J. Reynolds. 1997. The British retail system. Research report 97-06. Ryerson, Toronto: Centre for the Study of Commercial Activities. 
Clarke, I. 2000. Retail power, competition and local consumer choice in the UK grocery sector. European Journal of Marketing 34: 975-1002.

Clarke, I., A. G. Hallsworth, P. Jackson, R. Perez del Aguila, R. de Kervenoael, and M. Kirkup. 2006. Retail competition and consumer choice 1: Long-term local changes in consumer behaviour: Portsmouth, 1980-2002. Environment and Planning A 38: 25-46.

Clarke, I., M. Kirkup, and H. Oppewal. 2007. Are consumers getting what they REALLY want? Initial findings from a major survey of consumer satisfaction with their local selection of grocery stores. Paper presented at a workshop at the MIC Conference Centre, June 15, in London. http://www.competitioncommission.org.uk/inquiries/ref2006/grocery/index.htm

Competition Commission. 2000. Supermarkets: A report on the supply of groceries from multiple stores in the United Kingdom, Vol 1: Summary and Conclusions Cm 4842. London: The Stationery Office.

Competition Commission. 2008. Groceries Inquiry: final report. http://www.competition-commission.org.uk

Competition Commission. 2009. Remittal Response. http://www.competitioncommission.org.uk.

Cotterill, R. 1986. Market power in the retail food industry: Evidence from Vermont. Review of Economics and Statistics 68: 379-386.

Davies, R. 1978. Issues in retailing. In Issues in Urban Society, eds. R. Davies and P. Hall, Chapter 5. Harmondsworth: Penguin.

Dawson, J. A. ed. 1980, Retail geography. London: Croom Helm.

Dawson, J. 1983a. Retail Impact Studies. The Planner 69(1): 25.

Dawson, J. 1983b. Public policy controls on hypermarket development. Working Paper \# 8302. Stirling: Institute for Retail Studies.

Dawson, J. 2000. Retailing at century end. International Review of Retail, Distribution and Consumer Research 10(2): 119-148.

Dawson, J. A., and D. A. Kirby. 1980. Urban retail provision and consumer behaviour: some examples from Western society. In Geography and the urban environment, vol. 3, eds. D. T. Herbert and R. J. Johnston, 87-132. Chichester, Sussex: John Wiley.

Dawson, J. A., A. M. Findlay, and L. Sparks. 1986. Employment in British superstores. Working Paper \# 8601. Stirling: Institute for Retail Studies.

Department of the Environment. 1976a. The Eastleigh Carrefour: A hypermarket and its effects. Department of the Environment Research Report 16. London: The Stationary Office.

Department of the Environment. 1976b. Large New Stores. Department of the Environment Circular 71/76. London: The Stationary Office.

de Kervenoael, R., I. Clarke, and A. G. Hallsworth. 2006. Macro level change and micro-level effects: Long term change in food retailing in Britain. Journal of Retailing and Consumer services 13(6): 381-392.

Dobson, P. and M. Waterson. 1996. Vertical Restraints and Competition Policy RP 12, London: The Office of Fair Trading.

DuGay. P. 1996. Consumption and identity at work. London: Sage.

Fernie, J. and L. Sparks. 1998. Logistics and retail management. London: Kogan Page.

Fine, B., M. Heasman, and J. Wright. 1996. Consumption in the age of affluence. London: Routledge. 
Freeman, P. 2008. Is competition everything? Speech to the Law Society European, London.

Grocer (The). 2007. Asda exclusive. The Grocer, September 22.

Guy, C. 1990. Outshopping from small towns. International Journal of Retail and Distribution Management 18: 3-13.

Guy, C., G. P. Clarke, and H. Eyre. 2004. Food retail change and the growth of food deserts: a case study of Cardiff, International Journal of Retail \& Distribution Management 32: 72-88.

Hall, M., J. Knapp, and C. Winsten. 1961. Distribution in Great Britain and North America. Oxford: Oxford University Press.

Hallsworth, A. G. 1981a. Trading patterns of a district centre superstore: ASDA, Waterlooville. Occasional Publication, Department of Geography. Portsmouth: Portsmouth Polytechnic.

Hallsworth, A. G. 1981b. Trading patterns of a freestanding hypermarket: Havant, Hypermarket. Occasional Publication, Department of Geography. Portsmouth: Portsmouth Polytechnic.

Hallsworth, A.G. 1986. Hypermarkets and Superstores: Was Carrefour, Caerphilly, a red herring?, Cambria 12. 1-2.

Hallsworth, A. G. 1988. The human impact of hypermarkets and superstores, Aldershot: Gower Press.

Hallsworth, A. G. 1992. The new geography of consumer spending. London: Pinter publishers/ Belhaven.

Hallsworth, A G., and J. R. Bell. 2003. Retail change, and the UK co-operative movement a new opportunity beckoning. International Review of Retail Distribution and Consumer Research 13: 301-315.

Hogg, M. K. 1998. Anti-constellations: exploring the impact of negation on consumption. Journal of Marketing Management 14(1/3): 133-150.

Hughes, R., G. P. Clarke, and A. G. Hallsworth. 2009. Testing the effectiveness of the proposed UK 'Competition test'. The Service Industries Journal 29(5), 569590.

Jackson, P., R. Perez del Aguila, I. Clarke, A. G. Hallsworth, R. de Kervenoael, and M. Kirkup. 2006. Retail competition and consumer choice 2: Understanding consumer choice at the household level. Environment and Planning A 38: 47-67.

Jones, P. 1981. Retail innovation and diffusion - the spread of ASDA stores. AREA 13(3): 197-201.

Kirkup, M., A. G. Hallsworth, R. de Kervenoael, I. Clarke, R. Perez del Aguila, and P. Jackson. 2004. Inequalities in retail choice: exploring consumer experiences in suburban neighbourhoods. International Journal of Retail and Distribution Management 32: 511-522.

Langston, P., G. P. Clarke, and D. B. Clarke. 1997. Retail saturation, retail location, and retail competition: an analysis of British grocery retailing. Environment and Planning A 29: 77-104.

Lawlor, E. 1989. Individual choice and higher growth commission of the European communities. Brussels: Office for Official Publications of the European Community.

Lee M. S. W., K. V. Fernandez, and M. R. Hyman. 2009. Anti-consumption: An overview and research agenda. Journal of Business Research 62: 145-147.

Marion, B. W., W. F. Mueller. R. W. Cotterill. F. E. Geithman and J. R. Schmelzer. 1979. The food retailing industry: Market structure, profits and prices. New York: Praeger. 
Miller, D., ed. 1995. Acknowledging consumption: A review of new studies. London: Routledge.

Miller, D., P. Jackson. N. Thrift. B. Holbrook and M. Rowlands. 1998. Shopping, place and identity. London: Routledge.

Mintel. 2007. Children's clothing UK: December 2007. London: Mintel.

National Consumer Council. 1999. The consumer and the state: Getting value for public money. Amersham, Bucks: National Consumer Council.

New Economics Foundation. 2005. Clone Town Britain. London: NEF.

New Economics Foundation. 2006. Ghost Town Britain. London: NEF.

Pal, J., D. Bennison. I. Clarke, and J. Byrom. 2001. Power, policy networks and planning. The International Review of Retail, Distribution and Consumer Research 11(3): 225-246.

Piacentini, M., S. Hibbert, and H. Al-Dajani. 2001. Diversity in deprivation: Exploring the grocery shopping behaviour of disadvantaged consumers. International Review of Retail, Distribution and Consumer Research 11(2): 141158.

Pimlott, D. 2005. After the cuts, butchers in demand for quality meat. Financial Times, October 28.

Reynolds, J., E. Howard, and Dragun D. 2004. Assessing the productivity of the UK retail sector. Oxford: OXIRM Templeton College Oxford Report.

Simms, A. 2007. Tescopoly: How one shop came out on top and why it matters. London: Constable and Robinson.

Slade, M. 2008. Expert opinion on UK Groceries Market definition. http://www.competition-commission.org.uk

Sparks, L. 1996. The census of distribution: 25 years in the dark. AREA 28: 89-95.

Sparks, L. 2008. Commentary: When Tony met Bobby. Environment and Planning A 40: 2793-2799.

Straughan, P. 1992. Your food: Whose choice? National Consumer Council. London: The Stationary Office.

Wood, S., M. Lowe, and N. Wrigley. 2006. Life after PPG6 - recent UK retailer responses to planning regulation tightening. International Review of Retail, Distribution and Consumer Research 16(1): 23-41.

Warde, A. 2005. Consumption and theories of practice. Journal of Consumer Culture 5(2), 131-153.

Whysall, P. 2005. GEM, 1964-1966: Britain's first out-of-town retailer. International Review of Retail, Distribution and Consumer Research 15(2): 111-124.

Wortmann, M. (2004). Aldi and the German model. Competition \& Change 8(4), 425441

Wrigley, N. 1993. Abuses of market power? Environment and Planning A 25: 15451557.

Wrigley, N,. J. Branson, J, A. Murdock, and G. Clarke. 2009. Extending the Competition Commission's findings on entry and exit of small stores in British high streets: Implications for competition and planning policy. Environment and Planning A 41, 2063-2085. 